\author{
БРИЛЬ Марина Миколаӥвна, \\ кандидат психологічних наук, \\ Київський національний університет культури і мистецтв, \\ Київ, Україна, mbryl73@gmail.com \\ ORCID ID: https://orcid.org/0000-0003-1116-582
}

\title{
МЕНЕДЖЕР СОЦІОКУЛЬТУРНОЇ ДІЯЛЬНОСТІ ЯК СУБ'ЄКТ ІННОВАЦІЙ
}

Анотація. Актуальність зумовлена необхідністю вимог ринку праці отримувати професіонала-менеджера соціокультурної діяльності як сформовану особистість, суб'єкта, підготовленого до впровадження інновацій. Мета і методи. Мета - аналіз процесу формування особистості менеджера соціокультурної діяльності як суб'єкта інновацій у майбутньому професійному житті та обгрунтування ефективних методик впливу на цей процес під час їх підготовки. Методи дослідження: загальнонаукові методи аналізу та синтезу теоретичних положень теорії менеджменту та управління, порівняння та групування понять, аналіз наукової та методичної літератури, практичного досвіду. Результати проведеного дослідження дозволяють визначити важливість підготовки менеджерів соціокультурної сфери до впровадження інновацій безпосередньо як їх суб'єктів. Висновки та обговорення. В сучасних умовах постійно підвищуються вимоги до особистісних професійних рис фахівців. Більшість із них пов'язана з умовами невизначеності та інноваційності. Наукова новизна одержаних результатів дослідження полягає у виявленні впливу ефективно організованої навчальнопрактичної діяльності на саморозвиток та формування менеджера соціокультурної діяльності як суб'єкта інновацій, а практичне значення - в можливості запроваджувати на рівні форм та методів викладацької діяльності ефективні сучасні ідеї щодо формування інноваційного (правильного) мислення в менеджера. Перспективи подальших наукових розвідок полягають у тому, щоб на основі аналізу зворотного зв'язку від стейкхолдерів ринку соціокультурних послуг визначити значущі якості менеджера як суб'єкта інновацій та перевірити ефективність методик їх формування.

Ключові слова: особистість, менеджер, соціокультурна діяльність, суб'єкт, інновація, стандарт вищої освіти.

Брыль Марина Николаевна, кандидат психологических наук, Киевский национальный университет культуры и искусств, Киев, Украина, mbry $173 @$ gmail.com.

\section{Менеджер социокультурной деятельности как субъект инноваций}

Аннотация. Актуальность обусловлена требованиями современного рынка труда получать профессионала-менеджера социокультурной деятельности как сложившуюся личность, субъекта, подготовленного к внедрению инноваций. Цель и методы. Цель - анализ процесса формирования личности менеджера социокультурной деятельности как субъекта инноваций в будущей 
профессиональной жизни и обоснование эффективных методов воздействия на этот процесс во время их подготовки. Методы исследования: общенаучные методы анализа и синтеза положений теории менеджмента и управления, сравнение и группирование понятий, анализ научной и методической литературы, практического опыта. Результаты проведенного исследования позволяют отметить важность подготовки менеджеров социокультурной сферы к внедрению инноваций непосредственно как их субъектов. Выводы и обсуждение. В современных условиях постоянно повышаются требования к личностным профессиональным качествам специалистов. Научная новизна исследования заключается в выявлении влияния эффективно организованной учебно-практической деятельности на саморазвитие и формирование менеджера социокультурной деятельности как субъекта инноваций, а практическое значение состоит в возможности внедрения в преподавательскую деятельность на уровне разработки форм и методов эффективных современных идей, направленных на формирование инновационного (правильного) мышления у менеджера. Перспектива дальнейших научных исследований состоит в том, чтобы на основе анализа обратной связи от стейкхолдеров рынка социокультурных услуг определить значимые качества менеджера как субъекта инноваций и проверить эффективность методик их формирования.

Ключевые слова: личность, менеджер, социокультурная деятельность, субъект, инновация, стандарт высшего образования.

Bryl Maryna, PhD (Psychology), Kyiv National University of Culture and Arts, Kyiv, Ukraine, mbryl73@gmail.com.

\section{Manager of socio-cultural activity as a subject of innovations}

Abstract. Actuality. The significance is due to the requirements of the modern labor market to receive a professional manager of socio-cultural activity as a developed personality, an active subject prepared for the introduction and implementation of innovations. Purpose and methods. The goal is to analyze the process of the personality development in the socio-cultural manager's activity as the subject of innovations in the future professional life and to substantiate effective methods influencing this process during its preparation. Results. Research methods: general scientific methods of analysis and synthesis of the theory of management, comparison and grouping of concepts, scientific and methodological literature analysis and practical experience. The results of the research allow us to note the importance of training managers in the socio-cultural sphere to introduce innovations directly as their subjects. Conclusions and discussion. Nowadays the requirements for personal professional qualities are increasing constantly. The scientific novelty of the study findings is to identify the effect of well organized educational and practical activities on selfdevelopment and the formation of a manager in socio-cultural activity as a subject of innovation. Practical significance will make it possible to introduce effective modern ideas on the formation of manager's innovative (correct) thinking at the level of forms and methods of teaching, instilling students' skills to master the effective technologies of personal and professional self-development and self-training during the entire professional life period.

Keywords: personality, manager, socio-cultural activity, subject, innovation, higher education standard. 


\section{1. Актуальність проблеми Actuality of problem}

Сьогодні більшість проблем, з якими стикається менеджер, не схожі на ті, які виникали перед ним раніше. Відрізняються вони й від тих питань, які постануть перед менеджером завтра. Можна чітко визначити, що фахівці, які думають про їх вирішення вже зараз, мають шанс підготуватися до цього самостійно, а також створити умови для прийняття змін в організаціях, якими керують. Багато аспектів сучасного професійного життя зараз переноситься до сфери індивідуального саморозвитку, побудови кар'єри, й тому на часі гостро відчуваються питання формування актуальних професійних якостей фахівця.

Серед фахівців, на яких покладається завдання постійної готовності до впровадження інновацій, особливе місце посідають менеджери, спеціальність яких справедливо вважається однією з професій майбутнього. У теперішніх умовах організаціям у будь-яких сферах притаманні елементи інноваційної діяльності, робота з впровадження окремих інноваційних проектів. Сучасний професійний менеджер повинен мати таку кваліфікацію. Сьогодні на посадах менеджерів очікують фахівців різного рівня компетентності: від помічника менеджера до директора проекту (система сертифікації IPMA). Отже, різноманітні наукові, технічні, економічні, соціальні та психологічні аспекти в управлінні інноваційними, проектними процесами - це щоденні навички, які демонструє менеджер, бо сучасна економіка як середовище для діяльності сьогодні $є$ феноменом, що увібрав у себе знання, ризики, мережі, новації тощо. Така ситуація висуває певні вимоги до навчальних закладів, які впливають на формування якостей особистостей майбутніх менеджерів, пов'язаних з їх підготовкою до впровадження та управління інноваціями вже в професійному житті. Також фахівці такого рівня кваліфікації частіше за все самі виступають суб'єктами інновацій як їх автори та мотиватори.

Стан вивчення проблеми. Сучасна наука накопичила значний досвід у питаннях підготовки, індивідуально-професійного розвитку фахівців у галузі менеджменту. Досить великий обсяг літератури, присвяченої аналізу професійно значущих для менеджера якостей спеціаліста, існує в акмеології (А. Бодалев, Н. Кузьміна), психології (О. Бабенко, Г. Балл, Т. Баталова, Е. Вендров, Л. Карамушка, Г. Костюкова, С. Максименко, В. Москаленко, Л. Орбан-Лембрик, О. Силкін), менеджменті (М. Вудкок, Т. Дудар, Л. Краснова, В. Мельниченко, І. Степанова, А. Файоль, Д. Френcic, В. Шепель, С. Яголковський, Лі Якокка). Однак у вітчизняній науці «модель» сучасної особистості менеджера ще не є остаточно та досконало сформованою. Найбільш актуальні, на наш погляд, якості особис- 
тості менеджера як суб'єкта інновацій останнім часом розглядалися в наукових працях вітчизняних (М. Аль Атум (2014), Т. Дудар, Т. Глушман (2016), Я. Мартинишин (Обгрунтування..., 2017), В. Мельниченко (2008), В. Рач, О. Медведєва (2015), О. Россошанська (2010), І. Тодорова (2017)), а також зарубіжних авторів (П. Друкер (2004), Р. Фрімен (Freeman, 2004)). Також на увагу заслуговують публікації на цю тему таких авторів, як М. Діденко (2013), Н. Димченко (2013), Н. Жигайло (2014) та ін.

Невирішені питання. Треба відзначити, що сьогодні дуже широко у менеджменті застосовується методологія управління проектами в різних галузях. Однак питання визначального чинника ролі особистості в успіху будь-якого проекту в галузі соціокультурної сфери вивчено ще недосконало. Образ нового бачення моделі менеджера соціокультурної сфери передбачає обгрунтування нових компетенцій, в основі яких лежать концепція нового управлінського мислення, механізм рефлексії, увага до «м'якого» (пов'язаного з особистістю, стосунками, взаємодією) компоненту. Сучасний менеджер постійно працює в середовищі нових об'єктів та сам стає суб'єктом інновацій у власній діяльності: він будує моделі рішень та діяльності, генерує нові знання, управляє взаємодією, відхиленнями, ризиками тощо. Але актуальність такої підготовки у вигляді формування компетентності під час навчання бакалаврів та магістрів ще потребує впровадження в навчальний процес. У наш час подібна підготовка зазвичай більше пов'язана із бізнес- або корпоративним навчанням.

\section{2. Мета і методи дослідження Purpose and research methods}

Мета статті - аналіз процесу формування особистості менеджера соціокультурної діяльності як суб'єкта інновацій у майбутньому професійному житті та обгрунтування ефективних способів і методів впливу на цей процес.

Методологічною основою дослідження $є$ діалектичні ідеї про взаємозв'язок розвитку теорії та практики, загальнонауковий системний підхід до вивчення особистості менеджера соціокультурної діяльності.

Методи дослідження. Ця робота має теоретичну спрямованість. У дослідженні використовуються загальнонаукові методи аналізу і синтезу положень теорії менеджменту й управління, порівняння та групування понять, аналіз наукової і методичної літератури, практичного досвіду.

Інформаційна база дослідження - монографічні дослідження, фахові посібники зі стратегічного, інноваційного, креативного менеджменту, періодична фахова наукова література, нормативні документи (проекти стандартів із менеджменту соціокультурної діяльності), спостереження та узагальнення, отримані під час науково-педагогічної діяльності. 


\section{3. Результати дослідження Research results}

Особистість є досить розробленою категорією у психології. Різноманітність концепцій особистості підкреслює, що ії зміст доволі багатогранний. Це складне соціальне поняття, яке характеризується рівнем розвитку психіки, іiі здатністю до опанування соціальним досвідом. Особистість посідає певне становище, виконує багато ролей у суспільстві. Відомі науковці з управління проектами $B$. Рач, О. Медведєва (2015) у контексті нашого дослідження стверджують: «Особистість - це кожна людина, яка є індивідуальною, унікальною, геніальною завдяки своїм знанням та здібностями» (с. 112).

У науках про людину використовується поняття «формування особистості», яке вживається у двох значеннях. Перше (психологічний підхід) - формування особистості як розвиток, процес і результат. У цьому значенні формування особистості є предметом того, що є в наявності та що може виникнути в особі в умовах цілеспрямованих виховних і навчальних дій. Друге (педагогічний підхід) - формування особистості як іiі цілеспрямоване виховання. Воно передбачає необхідність з'ясування, що і як повинно бути сформовано в особистості, аби вона відповідала соціально зумовленим вимогам, які висуває суспільство.

Основним результатом навчально-виховного процесу у вищому навчальному закладі є сформована особистість випускника - фахівця професійної сфери. Останнім часом вимоги до нього змінилися та осучаснилися. Багато професій вимагають конкретних рис особистості, які пов'язані з виконанням професійних вимог. Перше п'ятнадцятиріччя XXI ст. ознаменувалося в нашій країні введенням у практику основних положень міжнародних актів із питань модернізації освіти. Певною віхою в іiі реформуванні став Закон України «Про вищу освіту» (2014р.). Одним із провідних у ньому було визначено поняття «стандарт вищої освіти». Стандарт (від англ. standard (норма, взірець)) у більш широкому значенні еталон, модель, що застосовується як вихідний зразок для зіставлення з подібним до нього об'єктом. Поняття «стандарту» стосовно освіти розтлумачується і як система параметрів, що виступають державною нормою освіченості, відповідності до соціального ідеалу та враховує можливості реальної особистості й системи освіти до його досягнення. Виходячи з цього, за своєю сутністю «освітній стандарт» - це документ, який встановлює певні норми реалізації освітнього процесу. Стандарти включають опис результатів навчання, необхідних для присудження кваліфікації випускникам навчальних закладів. Дослідниця Н. Дупак (2010) вважає, що освітній стандарт характеризується й рівнем загальної та професійної культури суспільства, формуванням у тих, хто навчається, 
картини світу, адекватної рівням знань і освітньої програми (ступенів навчання), інтеграцією особистості в національну та світову культуру, формуванням людини і громадянина, «вписаного» в сучасне йому суспільство й націленого на вдосконалювання нього, відтворення і розвиток кадрового потенціалу. Автор визначає освітній стандарт як своєрідний «інформаційний ген» (с. 54).

Щодо вимог до стандарту фахівців - випускників спеціальності галузі «Культура і мистецтво» за шифром 028 «Менеджмент соціокультурної діяльності», треба зазначити, що проекти цих стандартів 3'явилися у 2016 та 2017 рр. та відбивають у своєму змісті одну із головних (інтегральну) компетенцію, яка відповідає затвердженій Національній рамці кваліфікацій (2010р.) та пов'язана насамперед із різним рівнем готовності до впровадження інновацій зазначених рівнів вищої освіти (табл. 1).

Табл. 1. Порівняння змісту інтегральної компетентності стандартів спеціальності 028 «Менеджмент соціокультурної діяльності»

Tab. 1. Comparison in the contents of integral competence of the standards of specialty 028 «Management of socio-cultural activities»

\begin{tabular}{|c|c|c|}
\hline \multirow{2}{*}{$\begin{array}{c}\text { Показ- } \\
\text { ники }\end{array}$} & \multicolumn{2}{|c|}{ Рівень вищої освіти } \\
\hline & Перший - бакалаврський & Другий - магістрський \\
\hline 点 & $\begin{array}{l}\text { Здатність розв’язувати складні } \\
\text { спеціалізовані завдання та прак- } \\
\text { тичні проблеми у соціокультурній } \\
\text { сфері, у сфері освіти та науки, } \\
\text { що передбачає застосування } \\
\text { теорій та методів менеджменту } \\
\text { культури і характеризується } \\
\text { комплексністю та невизначе- } \\
\text { ністю умов }\end{array}$ & $\begin{array}{l}\text { Здатність розв’язувати складні } \\
\text { завдання і проблеми в менедж- } \\
\text { менті соціокультурної діяльності } \\
\text { або у процесі навчання, що перед- } \\
\text { бачає проведення досліджень } \\
\text { та/або здійснення інновацій та } \\
\text { характеризується невизначеністю } \\
\text { умов і вимог до практичного засто- } \\
\text { сування набутих компетентностей }\end{array}$ \\
\hline
\end{tabular}

Джерело: розроблено на основі (Проекти..., 2016-2017)

Source: developed on the basis of (Proekty..., 2016-2017)

Таким чином, як бачимо, здатність вирішувати складні спеціалізовані завдання та практичні проблеми комплексно у невизначених умовах вже характеризує діяльність менеджера-бакалавра як суб'єкта діяльності, а програма підготовки магістра передбачає ще більш «просунутий» рівень, пов'язаний із ефективним використанням завдань інноваційного характеру у комплексі з невизначеними умовами та складними дослідницькими завданнями.

Відомо, що існує перелік від 30 до 100 вимог, що в цілому висуваються до формування якостей професійного менеджера (Димченко, 2013). Але можна з упевненістю стверджувати, що в світі немає жодної людини, яка б одна втілювала хоча б половину з них. У загальному виг- 
ляді за запропонованим підходом Н. Димченко (2013) основа професійних якостей для менеджера має такий вигляд за кваліфікаціями: концептуальна, кваліфіковані людські стосунки, ділова (адміністративна), фахова (с. 10-11); за підходом М. Діденко (2013), набір професійно значущих якостей майбутніх менеджерів можна об'єднати у чотири блоки: лідерський, комунікативний, емоційно-вольовий, діяльнісний (с. 210).

Менеджер - це суб'єкт, управлінець ринкової орієнтації, який активно впроваджує ефективні умови господарювання, нововведення та досягнення науково-технічного прогресу, виважено враховує зміни в міжнародних відносинах, своєчасно впливає на кон'юнктуру та динаміку попиту, пропозиції, вміло перебудовує виробничо-господарську діяльність з урахуванням вимог ринку. Менеджер - це не тільки професіонал, це - особистість, яка є суб'єктом праці у сфері управління. Якісною характеристикою менеджера як суб'єкта праці є професіоналізм риса, що показує рівень розвитку особистісних професійно необхідних якостей. Така інтеграція відбивається у визначенні, яке дають Н. Жигайло, Р. Карпінська (2014): «Професіонал - це суб'єкт професійної діяльності, який володіє високими показниками професіоналізму особистості й діяльності, має високий професійний та соціальний статус, і систему особистісно-дійової нормативної регуляції, що динамічно розвивається, постійно націлений на саморозвиток і самовдосконалення, на особистісні й професійні досягнення, які мають соціально-позитивне значення» (с. 230).

Як і в інших галузях менеджменту, менеджер у соціокультурній діяльності повинен розуміти свій головний обов'язок: забезпечення результативності роботи в досягненні цілей організації при ефективному та раціональному використанні наявних ресурсів. Концептуальними необхідними навичками тут стають когнітивні (пізнавальні) здібності сприймати організацію як ціле, мислення менеджера, вміння обробляти інформацію, планувати, виробляти та впроваджувати інноваційні ідеї.

Інновацію визначають як об'єкт, ідею, дію, які сприймаються споживачем (людиною або організаційною структурою) як нові (Яголковский, 2007, с. 68). Можна говорити про особистісну та групову інноваційність. Як об'єкт аналізу нас цікавить саме особистісна. Інноваційність здатність людини на когнітивному i, якщо це необхідно, поведінковому рівнях забезпечити появу, сприйняття і можливу реалізацію цих ідей (Там само, с. 72). Але впровадження інноваційних ідей частіше за все виявляє значні труднощі на практиці, серед яких значна вага лежить на психологічних чинниках: стереотипності, консервативності тощо. Особливу важливість у їх подоланні може грати гнучкість мислення учасників інноваційного процесу. У цьому аспекті дуже цікавою $є$ ідея мислення НІКС-методології, яку представляє у своїх роботах наукова школа відомого українського вченого В. Рача (М. Аль Атум, О. Медведєва, 
О. Россошанська та ін.). Вона базується на гармонізованому формуванні чотирьох аспектів цілісного мислення: нечіткого, інтерактивного, креативного та системного. ВзаємоСОдія (термін школи) цих чотирьох аспектів дозволяє менеджерам ефективно генерувати інноваційне розв'язання погано структурованої проблемної ситуації. Ці аспекти повинні замінити традиційні аспекти мислення: чіткість, реактивність, стандартність, фрагментарність. У зв'язку з цим постає актуальним завдання на етапах підготовки бакалаврів та магістрів закладати фундамент цілісного (правильного) мислення менеджерів, яке буде включати таку компетенцію менеджерів до власного психологічного менеджменту за допомогою рефлексії як основи для виділення в навколишньому середовищі нових об'єктів, нових зв'язків між ними, побудови нових категорійних моделей, пошуку нових способів представлення їх поняттєвої сутності та онтологічної інтерпретації проектної діяльності (Рач \& Медведєва, 2015, с. 110). Тобто мова йде про окремий вид мислення - «інноваційне мислення», яке уподібнюють гнучкому, креативному, творчому, і визначається як здатність людини змінювати настанови в умовах постійно змінної реальності.

В умовах навчального процесу підготовки менеджерів соціокультурної діяльності на 3-4-му роках навчання нами було запропоновано курс «Комплексного психологічного тренінгу з розвитку креативності», який, на нашу думку, міг би частково реалізовувати завдання підготовки менеджерів як суб'єктів інновацій. Курс був призначений для студентів освітніх програм «Менеджмент модельного бізнесу», майбутні професії яких пов'язані з пошуком, втіленням та аналізом впровадження нових творчих рішень у різних видах діяльності - управлінській, творчій, інноваційній. До реалізації комплексного тренінгу було включено теоретичну (лекційну) частину: викладання базових уявлень про сутність креативності/інноваційності, знайомство з підходами до їх визначення, опис основних аспектів іiї вивчення; знайомство з новими методами розвитку креативності як першого кроку до інноваційності. Певна увага приділялася питанням впливу творчого середовища, спілкування та міжособистісної взаємодії на формування креативності суб'єкта. Практична частина програми тренінгу включала тренування креативності за допомогою навчальних та практичних ситуацій, вправ, підготовки творчих завдань, складання власної програми саморозвитку креативності. До самостійної роботи також увійшло засвоєння та знайомство з теоретичним матеріалом наукової періодики, присвяченої проблемам готовності до впровадження інновацій та розвитку креативності, написання власних есе. Процесуальна характеристика комплексного тренінгу як тренування розвитку креативності студентів передбачала: засвоєння та перетворення теоретичної інформації у сфері психології розвитку креативності за допомогою механізмів рефлексії на розвинуту навичку, звички до 
інноваційного мислення; психологічне моделювання власної індивідуальної (унікальної) структури креативності; розроблення та реалізацію програми кар'єрного саморозвитку; розроблення креативних проектів у навчальній/професійній сфері. Два роки впровадження тренінгу показали, що необхідно щорічно переглядати як деякі теоретичні положення, так і практичні напрацювання програми, роблячи її більш актуальною та спрямованою на підвищення конкурентоспроможності менеджерів як суб'єктів інновацій.

\section{4. Висновки та обговорення результатів Conclusions and discussion of results}

Результати проведеного дослідження дозволяють визначити важливість підготовки менеджерів соціокультурної сфери до впровадження інновацій безпосередньо як їх суб'єктів та дійти таких висновків:

1. У сучасних умовах підвищуються вимоги до особистісних професійних рис, необхідних для виконання функцій менеджера соціокультурної діяльності. Більшість із них пов'язана з умовами невизначеності та інноваційності, в яких сам менеджер виступає як суб'єкт.

2. Такі риси мають не тільки вроджений характер, а можуть бути розвинуті у спеціально організованих умовах. На початку професійної кар'єри менеджера у цьому процесі провідну роль грають умови вищого навчального закладу, який має прищепити майбутньому фахівцю необхідні для виконання професійних обов'язків риси - сучасне мислення. Для нинішнього покоління керівників стає актуальною наявність нечіткого, інтерактивного, креативно-конструктивного, системного мислення, яке можна було б назвати позитивним та правильним, що долає перешкоди і бар'єри, які ми встановлюємо самі собі і які виникають у світі, де частіше проявляються хаос і безладдя. Завдання менеджера формувати в собі ресурси для заохочення як групової, так й індивідуальної творчості, джерело яких у психологічному менеджменті - професійній рефлексії та саморозвитку.

3. Формування ефективного менеджера як суб'єкта інновацій повинно враховувати нові тенденції в науці: педагогіці, психології, теорії та практиці менеджменту, бути гнучким та пристосовуватися під запити ринку праці.

Наукова новизна одержаних результатів дослідження полягає у виявленні впливу ефективно організованої навчально-практичної діяльності на саморозвиток та формування менеджера соціокультурної діяльності як суб'єкта інновацій.

Практичне значення роботи виявляється в можливості заправаджувати на рівні форм та методів викладацької діяльності ефективні сучасні ідеї щодо формування інноваційного (правильного) мислення у 
менеджера, прищеплювати студентам навички до опанування дійовими технологіями саморозвитку та самонавчання фахівця протягом усього професійного періоду життя.

Перспективи подальших наукових розвідок полягають у тому, щоб на основі нашого теоретичного дослідження за допомогою опитування випускників - менеджерів соціокультурної сфери, які вже працюють, інших стейкхолдерів ринку професійних соціокультурних послуг - визначити значущі якості для організації управління діяльністю як суб'єкта інновацій та ефективні методики і методи їх формування в умовах навчання у вищому навчальному закладі.

\section{Література}

Аль Атум М. Метод планирования содержания мягких проектов по критерию важности формируемых компетентностей. Управління проектами та розвиток виробництва. 2014. № 3 (51). С. 116-129.

Вудкок М., Фрэнсис Д. Раскрепощенный менеджер : для руководителяпрактика. Пер. с англ. Москва : Дело, 1991. 365 с.

Глушман Т. М. Компоненти професійної культури майбутнього менеджера організацій. Scientific Journal «ScienceRise: Pedagogical Education». 2016. № 5 (1). C. 8-13.

Димченко Н. С. Модель сучасного менеджера-професіонала. Вісник Сумського національного аграрного університету Серія «Економіка і менеджмент». 2013. Вип. 12 (58). С. 10-13.

Діденко М. С. Професійно значимі якості особистості менеджера організацій: теоретичний аспект. Міжнародний науковий форум: соџіологія, психологія, педагогіка, менеджмент. 2013. Вип. 13. С. 201-211.

Друкер П. Ф. Задачи менеджмента в XXI веке. Пер. с англ. Москва : Вильямс, 2004. 272 с.

Дудар Т. Г., Мельниченко В. В. Інноваційний менеджмент. Тернопіль : Економічна думка, 2008. 250 с.

Дупак Н. В. Стандартизація в галузі освіти як комплексна проблема. Вісник Житомирського держ. ун.-ту. 2010. Вип. 52. С. 53-57.

Жигайло Н. І., Карпінська Р. І. Психологія професійного і духовного становлення керівника. Проблеми сучасної психології. 2014. Вип. 24. С. 228-239.

Краснова Л. В. Управление инновациями: работа в команде и задачи менеджера. Известия РГПУ им. А. И. Гериена. 2008. С. 336-340.

Обгрунтування парадигми менеджмент-освіти у соціокультурній сфері. За ред. Я. М. Мартинишина. Біла Церква : Вид. О. В. Пшонківський, 2017. 509 c.

Проекти стандартів вищої освіти. 028 Менеджмент соціокультурної діяльності (бакалавр, 2016, магістр 2017). doi: mon.gov.ua/ua/osvita/vishaosvita/naukovo-metodichna-rada-ministerstva-osviti-i-nauki-ukrayini/ proekti-standartiv-vishoyi-osviti (дата звернення : 10.03.2018). 
Рач В. А., Медведєва О. М. Комунікаційно-знаннєва онтологія формування мисленнєвої НІКС-методології менеджерів проектів. Управління проектами та розвиток виробництва. 2015. № 4 (56). С. 109-123.

Россошанская О. В. Культурный контекст проекта как элемент компетентностного подхода в управлении проектами. Управління проектами та розвиток виробництвва. 2010. № 2 (34). С. 147-155.

Тодорова I. С., Бульченко Д. В. Розвиток креативно-інноваційного потенціалу майбутніх менеджерів. Психологія і особистість 2017. № 1 (11). C. 258-267. DOI: https://doi.org/10.5281/zenodo.260215

Яголковский С. Р. Психология креативности и инноваций. Москва : ВШЭ, 2007. 157 c.

Freeman R. E. Strategic Management: a Stakeholder Approach. Boston : Pitman, 1984. $275 \mathrm{p}$.

Individual Competence Baseline for Project, Program and Portfolio Management. Version 4.0. IPMA Global Standard. 2015. URL: products.ipma. world/wpcontent/uploadsWEB.pdf. (дата звернення : 05.02.2018).

Стаття надійшла до редакції 20.02.2018

\section{References}

Al Atum, M. (2014). Metod planirovaniia soderzhaniia miagkikh proektov po kriteriiu vazhnosti formiruemykh kompetentnostei [The method of planning soft projects by the criterion of the importance of the formed competencies]. Upravlinnia proektami ta rozvitok virobnitstva [Project management and production development],3 (51),116-119 (in Russ.).

Didenko, M. S. (2013). Profesijno znachymi iakosti osobystosti menedzhera orhanizatsij: teoretychnyj aspekt [Professionally significant personality qualities of the manager of organizations: theoretical aspect]. Mizhnarodnyj naukovyj forum: sotsiolohiia, psykholohiia, pedahohika, menedzhment [International scientific forum: sociology, psychology, pedagogy, management], 13, 201-211 (in Ukr.).

Druker, P. F. (2004). Zadachy menedzhmenta v XXI veke [Management tasks in the 21st century]. (Trans. in Eng.). Moscow: Vyliams (in Russ.).

Dudar, T. H., \& Melnychenko, V. V. (2008). Innovatsijnyj menedzhment [Innovation management]. Ternopil: Ekonomichna dumka (in Ukr.).

Dupak, N. V. (2010). Standartyzatsiia v haluzi osvity iak kompleksna problema [Standardization in the field of education as a complex problem]. Visnyk Zhytomyrskoho derzh. un.-tu [Bulletin of Zhytomyr State University], 52, 53-57 (in Ukr.).

Dymchenko, N. S. (2013). Model suchasnoho menedzhera-profesionala [Model of modern manager-professional]. Visnyk Sumskoho natsionalnoho ahrarnoho universytetu. Seriia «Ekonomika i menedzhment» [Bulletin of the Sumy National Agrarian University. Series «Economics and Management»], 12 (58), 10-13 (in Ukr.).

Freeman, R. E. (1984). Strategic Management: a Stakeholder Approach. Boston: Pitman. 
Hlushman, T. M. (2016). Komponenty profesijnoi kultury majbutnoho menedzhera orhanizatsij [Components of the professional culture of the future manager of organizations]. Scientific Journal «ScienceRise: Pedagogical Education, 5 (1), 8-13 (in Ukr.).

Iagolkovskii, S. R. (2007). Psikhologiia kreativnosti i innovatsii [Psychology of creativity and innovation]. Moscow: VShE (in Russ.).

Individual Competence Baseline for Project, Program and Portfolio Management. Version 4.0. IPMA Global Standard. 2015. Retrieved from http:// products.ipmaworld/wpcontentWEB.pdf.

Krasnova, L. V. (2008). Upravlenie innovatsiiami: rabota v komande i zadachi menedzhera [Innovation management: teamwork and manager tasks]. Izvestiia RGPU im. A. I. Gertsena [News of the RSPU. A. I. Herzena], 336-340 (in Russ.).

Martynyshyn, Y. M. (Ed.). (2017). Obgruntuvannia paradyhmy menedzhmentosvity $u$ sotsiokulturnij sferi [Substantiation of the paradigm of management education in the socio-cultural sphere]. Bila Tserkva: Vydavets O. V. Pshonkivskyj (in Ukr.).

Proekty standartiv vyschoi osvity. 028 Menedzhment sotsiokulturnoi diialnosti (bakalavr, 2016, mahistr 2017) [Projects of higher education standards. 028 Management of Socio-Cultural Activities (Bachelor, 2016, Master 2017)]. doi:mon.gov.ua/ua/osvita/visha-osvita/naukovometodichnaministerstva-nauki-ukrayini/proekti-standartiv-vishoyi-osviti (in Ukr.).

Rach, V. A., \& Medvedieva, O. M. (2015). Komunikatsijno-znannieva ontolohiia formuvannia myslennievoi NIKS-metodolohii menedzheriv proektiv [Komunikatsionno-znannieva ontology of the formulary of the UICS-methodological project manager]. Upravlinnia proektamy ta rozvytok vyrobnytstva [Project management and production development], 4 (56), 109-123 (in Ukr.).

Rossoshanskaia, O. V. (2010). Kulturnyi kontekst proekta kak element kompetentnostnogo podkhoda $\mathrm{v}$ upravlenii proektami [The cultural context of the project as an element of the competence approach in project management]. Upravlinnia proektamy ta rozvytok vyrobnytstva [Project management and production development], 2 (34), 147-155 (in Russ.).

Todorova, I. S., \& Bulchenko, D. V. (2017). Rozvytok kreatyvno-innovatsijnoho potentsialu majbutnikh menedzheriv [Development of creativity and innovation potential of future managers]. Psykholohiia i osobystist [Psychology and personality], 1 (11), 258-267. DOI: https://doi.org/10.5281/zenodo.260215 (in Ukr.).

Vudkok, M., \& Frensis, D. (1991). Raskreposhchennyi menedzher: dlia rukovoditelia-praktik [Emancipated manager: for the head-practitioner] (Trans. in Eng.). Moscow: Delo (in Russ.).

Zhyhajlo, N. I., \& Karpinska, R. I. (2014). Psykholohiia profesijnoho i dukhovnoho stanovlennia kerivnyka [Psychology of professional and spiritual formation of the head]. Problemy suchasnoi psykholohii [Problems of modern psychology], 24, 228-239 (in Ukr.). 